\title{
Male Participation in Childbirth in Muaro Jambi Regency Indonesia
}

\author{
Guspianto ${ }^{1, *}$ Ismi Nurwaqiah Ibnu ${ }^{2}$ \\ 12 Study Program of Public Health Science, Faculty of Medicine and Health Sciences, Universitas Jambi. Jalan Tri \\ Brata, KM.11, Pondok Meja Mestong Muaro Jambi. 36364, Jambi Province, Indonesia \\ ${ }^{*}$ Corresponding author.Email: guspianto@unja.ac.id
}

\begin{abstract}
Male participation affects decision making in finding, reaching, and utilizing childbirth services, especially when women's capacity in decision-making is very limited, lack of access to health resources, heavy workloads, less supportive cultural norms and gender discrimination. This study aims to assess the level of male participation and to analyze the determinants of male participation in childbirth. A cross-sectional study was conducted through a survey of 381 men selected by multistage random sampling in Muaro Jambi District from July to September 2020. The dependent variable was male participation in childbirth and was constructed from six dichotomized indicators. A multiple logistic regression analyses technique was performed using SPSS 24.0 at a significance level of 0.05 . The majority of male participations in childbirth in Muaro Jambi Regency was high (54.1\%). Simultaneously, the factors related to male participation in childbirth were age $(\mathrm{OR}=2.148)$, wife's education $(\mathrm{OR}=2.158)$, income $(\mathrm{OR}=$ $2.092)$, communication $(\mathrm{OR}=2.594)$, and culture $(\mathrm{OR}=80.22)$. Cultural factor was the most important determinants of male participation in childbirth. Cultural factor was the main determinants of male participation in childbirth in Muaro Jambi District. Information dissemination and advocacy personally and structurally in society need to be done to reduce gender role inequality in decision-making and action to increase male participation in maternal health, especially in childbirth.
\end{abstract}

Keywords: Male participation, Childbirth.

\section{INTRODUCTION}

The World Health Organization (WHO) estimates approximately 810 women die every day related to pregnancy and childbirth, yet they are preventable through good health care before, during and after childbirth. The maternal mortality rate (MMR) in Indonesia was 305 per 100,000 live births in 2016, which is the second highest in Southeast Asia after Laos. In Jambi Province, MMR experienced fluctuations in which $81 / 100,000$ (2015) increased to $87 / 100,000$ (2016) and decreased again by $78 /$ 100,000 (2017). Efforts to reduce MMR in Indonesia are priority targets for SDG's (Sustainable Development Goals) of 70/100,000 in 2030[1].

The role of male in maternal health to reduce MMR has been an interesting discussion which has continued to increase in the last few decades, especially in areas that have traditionally considered it the responsibility of women. The International Conference on Population and Development (ICPD) in Cairo mandated that improving maternal health requires responsibility and active participation of males. The benefits of male's involvement in maternal health include increasing access and reducing barriers to access by skilled health workers and encouraging the influence of gender equality on maternal and child health to improve family quality. One form of male participation is taking a role when his wife gives birth.

The childbirth process carries a risk of complications such as bleeding, eclampsia, and others, which require services preparedness of emergency and quality in a fast manner. Due to delays in handling, the risk of complications will result in maternal death. The delay factors in childbirth services were known as "3L", namely: late in making decisions; late in reaching health facilities; and too late to get help [2]. 
Male participation affects decision making to seek, reach, and take advantage of delivery services, including readiness for labor and anticipation of complications of childbirth such as planned place and assisted childbirth process, delivered and accompanied his wife during childbirth, prepared transportation and funds during labor or emergency [3][4][5]. This is mainly done when women's limited capacity in decision making, lack of access to health resources, heavy workloads, cultural norms and gender discrimination [6].

Several studies have reported factors that contribute to male participation in childbirth, including the number of children, location of residence, waiting time, access to information, husband-wife communication, age, education, wife's employment status and pregnancy status [7][8][9]. This study aims to assess the level of male participation and to analyze determinants of male participation in childbirth.

\section{METHOD}

\subsection{Design and sampling}

A quantitative survey research using a cross sectional design was carried out on men of reproductive age couples who live in the same house with their partners and have had biological children aged up to 2 years at the time of data collection from June to August 2020 in Muaro Jambi Regency. The sample size was calculated based on Slovin formula with an error tolerance level of $5 \%$ and added $10 \%$ of the sample to anticipate non-response so that the total sample was 438 respondents. The response rate was $87 \%$ where only 381 samples were successfully interviewed. Sample selection used a multistage sampling technique, starting from randomly selecting 4 out of 11 sub-districts, then from the 4 selected sub-districts 2 villages were taken each so that a total of 8 villages were obtained. Samples from each village were randomly selected proportionally based on the household.

\subsection{Data management and analysis}

Data collection used a questionnaire developed by the researcher himself, adapted from several previous studies [8][9][10][11] and added some indicators from the Maternity Planning and Complications Prevention Program (P4K). The informed consent form was included on the first page of the questionnaire, and this study has received ethical approval from the health research ethics commission of the Health Polytechnic of the Ministry of Health Jambi, No: LB.02.06 / 2/109/2020.

The dependent variable is the male participation in childbirth was constructed as a composite variable of 6 question items with dichotomous answers (yes / no), namely: 1) plan the time and place of childbirth; 2) prepare a vehicle when needed during chilbirth; 3) prepare funds for delivery cost; 4) prepare blood donors candidates in case of labor emergency; 5) bring the wife when giving birth to the service place; 6) accompany the wife during childbirth. The level of male participation was categorized into 2, namely low and high based on the cut-off point skor (median).

The independent variables were characteristics and background of respondents consisting of age, number of children, income, education, wife's education, knowledge, distance, costs, transportation, health insurance, service quality, communication, social media information, and culture. Univariate analysis was carried out to obtain the frequency and percentage of characteristics and background of respondents as well as the level of male participation in childbirth, and to see the factors that determine male participation in childbirth using multiple logistic regressions.

\section{RESULTS}

\subsection{Characteristics and backgrounds of respondents}

Respondents' ages ranged from 21-56 years and the majority were $25-44$ years old $(78.2 \%)$. The number of children ranged from 1-6 children and most of them had 1-2 children $(77.4 \%)$. The average respondent's income was Rp. 2,299,737, - per month and the majority of income $\leqslant$ Rp. 2,500,000 (69\%). More than half of them have low education, both the respondents themselves $(59.8 \%)$ and the respondents' wives $(62.2 \%)$. The majority of respondents have good knowledge $(56.7 \%)$, close to childbirth service facilities $(90.6 \%)$, cheap delivery costs $(68 \%)$, easy transportation $(92.9 \%)$, have health insurance $(68.5 \%)$ and good perception of service quality $(52.8 \%)$. Most of respondents admitted that they were not good communicating about maternal health with their wives $(75.6 \%)$, did not get maternal health information from social media $(71.7 \%)$, and had a supportive culture $(70.6 \%)$ (Table 1$)$

Table 1. Respondent characteristics and background

\begin{tabular}{|l|l|r|l|}
\hline \multicolumn{1}{|c|}{ Variable } & \multicolumn{1}{|c|}{ Category } & Frequency & \multicolumn{1}{c|}{$(\%)$} \\
\hline Age (years) & $-21-24$ & 7 & $(1.8)$ \\
& $-25-34$ & 124 & $(32.5)$ \\
& $-35-44$ & 174 & $(45.7)$ \\
& $-\geq 45$ & 76 & $(20.0)$ \\
\hline Number of Children & $-\leq 2$ & 295 & $(77.4)$ \\
\hline
\end{tabular}




\begin{tabular}{|c|c|c|c|}
\hline & $\begin{array}{l}-3-5 \\
-6 \\
\end{array}$ & $\begin{array}{r}85 \\
1 \\
\end{array}$ & $\begin{array}{l}(22.3) \\
(0.3)\end{array}$ \\
\hline Income & $\begin{array}{l}-\leq 2.500 .000 \\
-\quad 2.600 .000-5.000 .000 \\
-5.100 .000-10.000 .000\end{array}$ & $\begin{array}{r}263 \\
112 \\
6\end{array}$ & $\begin{array}{l}(69.0) \\
(29,4) \\
(1,6)\end{array}$ \\
\hline Husband's Education & $\begin{array}{l}\text { - Not attending school } \\
\text { - Primary school } \\
\text { - Junior high school } \\
\text { - Senior high school } \\
\text { - University }\end{array}$ & $\begin{array}{r}1 \\
112 \\
115 \\
139 \\
14\end{array}$ & $\begin{array}{l}(0.3) \\
(29.4) \\
(30.2) \\
(36.5) \\
(3.7)\end{array}$ \\
\hline Wife Education & $\begin{array}{l}\text { - Primary school } \\
\text { - Junior high school } \\
\text { - Senior high school } \\
\text { - University }\end{array}$ & $\begin{array}{r}96 \\
141 \\
134 \\
10\end{array}$ & $\begin{array}{l}(25.2) \\
(37.0) \\
(35.2) \\
(2.6) \\
\end{array}$ \\
\hline Knowledge & $\begin{array}{l}\text { - Low } \\
\text { - Good }\end{array}$ & $\begin{array}{l}165 \\
216\end{array}$ & $\begin{array}{l}(43.3) \\
(56.7)\end{array}$ \\
\hline Distance & $\begin{array}{ll}\text { - Far } \\
\text { - Near }\end{array}$ & $\begin{array}{r}36 \\
345 \\
\end{array}$ & $\begin{array}{l}(9.4) \\
(90.6) \\
\end{array}$ \\
\hline Cost & $\begin{array}{l}\text { - Expensive } \\
\text { - Cheap }\end{array}$ & $\begin{array}{l}122 \\
259\end{array}$ & $\begin{array}{l}(32.0) \\
(68.0)\end{array}$ \\
\hline Transportation & $\begin{array}{l}\text { - Difficult } \\
\text { - Easy }\end{array}$ & $\begin{array}{r}27 \\
354\end{array}$ & $\begin{array}{l}(7.1) \\
(92.9)\end{array}$ \\
\hline Health insurance & $\begin{array}{l}\text { - Do not have } \\
\text { - Have }\end{array}$ & $\begin{array}{l}120 \\
261 \\
\end{array}$ & $\begin{array}{l}(31.5) \\
(68.5) \\
\end{array}$ \\
\hline Service quality & $\begin{array}{l}\text { - Poor } \\
\text { - Good } \\
\end{array}$ & $\begin{array}{l}180 \\
261 \\
\end{array}$ & $\begin{array}{l}(47.2) \\
(52.8) \\
\end{array}$ \\
\hline Communication & $\begin{array}{l}\text { - Poor } \\
\text { - Good } \\
\end{array}$ & $\begin{array}{r}288 \\
93 \\
\end{array}$ & $\begin{array}{l}(75.6) \\
(24.4) \\
\end{array}$ \\
\hline Social Media Information & $\begin{array}{l}\text { - No } \\
\text { - Yes } \\
\end{array}$ & $\begin{array}{l}273 \\
108 \\
\end{array}$ & $\begin{array}{l}(71.7) \\
(28.3) \\
\end{array}$ \\
\hline Culture & $\begin{array}{l}\text { - Less supportive } \\
\text { - Supportive }\end{array}$ & $\begin{array}{l}112 \\
269\end{array}$ & $\begin{array}{l}(29.4) \\
(70.6)\end{array}$ \\
\hline
\end{tabular}

\section{2. $\quad$ Level of male participation in childbirth}

This study found that the most widely practiced male participation in childbirth is accompanying their wives when they are about to give birth and at least planning potential blood donors for emergency labor conditions (Figure 1). In general, more than half of respondents reported high male participation in childbirth (table 2).

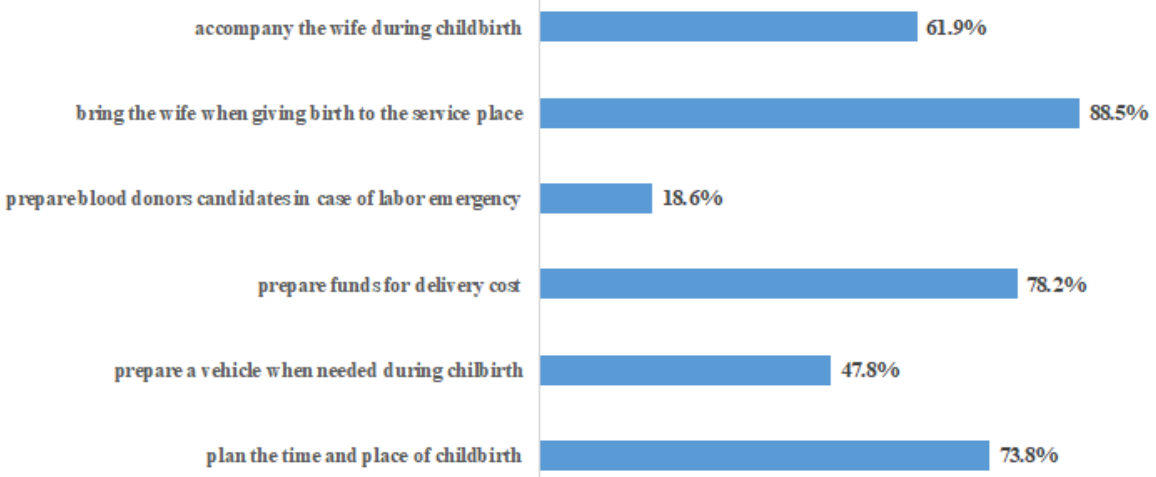

Figure 1. Components of Male Participation in Childbirth

Table 2. Level of male participation in childbirth

\begin{tabular}{|l|r|l|}
\hline Level of male participation in childbirth & Frequency & $(\%)$ \\
\hline - $\quad$ Low participation & 175 & $(45.9)$ \\
- High participation & 206 & $(54.1)$ \\
\hline
\end{tabular}




\subsection{Factors related to male participation in childbirth}

The results showed that of the 14 variables studied, there were 11 variables that were significantly related to the level of male participation in childbirth, namely age, income, wife's education, knowledge, distance, transportation, health insurance membership, service quality, communication, social media information, and culture (table 3).

Table 3. Relationship between respondent characteristics and background with male participation in childbirth

\begin{tabular}{|c|c|c|c|c|c|c|}
\hline \multirow{2}{*}{ Variabel } & \multicolumn{2}{|c|}{ Low Participation } & \multicolumn{2}{|c|}{ High Participation } & \multirow{2}{*}{$X^{2}$} & \multirow{2}{*}{ p-value } \\
\hline & $\mathrm{n}$ & $\%$ & $\mathrm{n}$ & $\%$ & & \\
\hline $\begin{array}{l}\text { Age } \\
-\quad \leq 30 \text { years } \\
-\quad>30 \text { years }\end{array}$ & $\begin{array}{l}53 \\
122\end{array}$ & $\begin{array}{l}58.2 \\
42.1\end{array}$ & $\begin{array}{l}38 \\
168\end{array}$ & $\begin{array}{l}41.8 \\
57.9\end{array}$ & 7.295 & $0.007 * *$ \\
\hline $\begin{array}{l}\text { Number of Children } \\
-\quad>2 \text { child } \\
-\quad \leq 2 \text { child }\end{array}$ & $\begin{array}{l}43 \\
132\end{array}$ & $\begin{array}{l}50.6 \\
44.6\end{array}$ & $\begin{array}{l}42 \\
164\end{array}$ & $\begin{array}{l}49.4 \\
55.4\end{array}$ & 0.955 & 0.328 \\
\hline \begin{tabular}{ll}
\multicolumn{2}{ll}{ Income } \\
$-\quad$ Low \\
$-\quad$ High
\end{tabular} & $\begin{array}{r}131 \\
44\end{array}$ & $\begin{array}{l}49.8 \\
37.3\end{array}$ & $\begin{array}{c}132 \\
74\end{array}$ & $\begin{array}{l}50.2 \\
62.7\end{array}$ & 5.143 & $0.023 *$ \\
\hline $\begin{array}{l}\text { Husband's Education } \\
-\quad \text { Low } \\
-\quad \text { High }\end{array}$ & $\begin{array}{r}111 \\
64\end{array}$ & $\begin{array}{l}48.7 \\
41.8\end{array}$ & $\begin{array}{c}117 \\
89\end{array}$ & $\begin{array}{l}51.3 \\
58.2\end{array}$ & 1.732 & 0.118 \\
\hline $\begin{array}{l}\text { Wife's Education } \\
-\quad \text { Low } \\
-\quad \text { High } \\
\end{array}$ & $\begin{array}{r}121 \\
54 \\
\end{array}$ & $\begin{array}{l}51.1 \\
37.5 \\
\end{array}$ & $\begin{array}{c}116 \\
90 \\
\end{array}$ & $\begin{array}{l}48.9 \\
62.5 \\
\end{array}$ & 6.627 & $0.010 * *$ \\
\hline $\begin{array}{ll}\text { Knowledge } \\
-\quad \text { Not Good } \\
-\quad \text { Good } \\
\end{array}$ & $\begin{array}{c}104 \\
71\end{array}$ & $\begin{array}{l}63.0 \\
32.9\end{array}$ & $\begin{array}{l}61 \\
145\end{array}$ & $\begin{array}{l}37.0 \\
67.1\end{array}$ & 34.262 & $0.000 * *$ \\
\hline $\begin{array}{ll}\text { Distance } \\
\text { - } & \text { Far } \\
- & \text { Near }\end{array}$ & $\begin{array}{l}23 \\
152\end{array}$ & $\begin{array}{l}63.9 \\
44.1\end{array}$ & $\begin{array}{l}13 \\
193\end{array}$ & $\begin{array}{l}36.1 \\
55.9\end{array}$ & 5.162 & $0.023 *$ \\
\hline $\begin{array}{l}\text { Cost } \\
-\quad \text { Expensive } \\
-\quad \text { Cheap }\end{array}$ & $\begin{array}{l}53 \\
122\end{array}$ & $\begin{array}{l}43.4 \\
47.1\end{array}$ & $\begin{array}{l}69 \\
137\end{array}$ & $\begin{array}{l}56.6 \\
52.9\end{array}$ & 0.448 & 0.503 \\
\hline $\begin{array}{ll}\text { Transportation } \\
-\quad \text { Difficult } \\
-\quad \text { Easy }\end{array}$ & $\begin{array}{l}18 \\
157\end{array}$ & $\begin{array}{l}66.7 \\
44.4\end{array}$ & $\begin{array}{l}9 \\
197\end{array}$ & $\begin{array}{l}33.3 \\
55.6\end{array}$ & 5.031 & $0.025^{*}$ \\
\hline $\begin{array}{l}\text { Health Insurance } \\
-\quad \text { No } \\
-\quad \text { Yes } \\
\end{array}$ & $\begin{array}{l}65 \\
110\end{array}$ & $\begin{array}{l}54.2 \\
42.1\end{array}$ & $\begin{array}{l}55 \\
151\end{array}$ & $\begin{array}{l}45.8 \\
57.9\end{array}$ & 4.783 & $0.029 *$ \\
\hline $\begin{array}{l}\text { Service Quality } \\
-\quad \text { Poor } \\
-\quad \text { Good }\end{array}$ & $\begin{array}{c}96 \\
78\end{array}$ & $\begin{array}{l}53.3 \\
39.0\end{array}$ & $\begin{array}{l}84 \\
122\end{array}$ & $\begin{array}{l}46.7 \\
61.0\end{array}$ & 7.841 & $0.005^{*}$ \\
\hline $\begin{array}{ll}\text { Communication } \\
-\quad \text { Poor } \\
-\quad \text { Good }\end{array}$ & $\begin{array}{c}144 \\
31\end{array}$ & $\begin{array}{l}50.0 \\
33.3\end{array}$ & $\begin{array}{c}144 \\
62\end{array}$ & $\begin{array}{l}50.0 \\
66.7\end{array}$ & 7.863 & $0.005^{*}$ \\
\hline $\begin{array}{l}\text { Social media information } \\
-\quad \text { No } \\
-\quad \text { Yes } \\
\end{array}$ & $\begin{array}{c}136 \\
39\end{array}$ & $\begin{array}{l}49.8 \\
36.1 \\
\end{array}$ & $\begin{array}{c}137 \\
69\end{array}$ & $\begin{array}{l}50.2 \\
63.9\end{array}$ & 5.853 & $0.016^{*}$ \\
\hline $\begin{array}{ll}\text { Culture } \\
-\quad \text { Less Supportive } \\
-\quad \text { Supportive }\end{array}$ & $\begin{array}{c}107 \\
68\end{array}$ & $\begin{array}{l}95.5 \\
25.3\end{array}$ & $\begin{array}{l}5 \\
201\end{array}$ & $\begin{array}{l}4.5 \\
74.7\end{array}$ & 157.169 & $0.000 *$ \\
\hline
\end{tabular}

Explanation : * $=\mathrm{p} \leq 0,05 ; * *=\mathrm{p} \leq 0,01 ; ; * * * \mathrm{p} \leq 0,001$

\subsection{Determinants of male participation in childbirth}

The results of the multivariate analysis (logistic regression) obtained 5 factors that determine the level of male participation in childbirth, namely age, wife's education, income, communication and culture. Men aged $>30$ years tended to have a higher participation rate in childbirth than men aged $\leqslant 30$ years. Men had $\leqslant 2$ children were more likely to participate in childbirth than those who had $>2$ children. Men with high income were more likely to participate in childbirth than those with low income, and men who had good knowledge were more likely to participate in childbirth than those who had less knowledge. The cultural factor was the main determinant factor related to male participation in childbirth (table 4). 
Table 4. Multivariate logistic regression analysis; Determinants of male participation in childbirth

\begin{tabular}{|l|l|l|l|l|}
\hline \multicolumn{1}{|c|}{ Variable } & \multicolumn{1}{|c|}{ B } & \multicolumn{1}{c|}{ P-Wald } & \multicolumn{1}{c|}{ OR $\operatorname{Exp(B)}$} & 95\% CI \\
\hline Age & 0,765 & $0,025^{*}$ & 2,148 & $1,103-4,185$ \\
\hline Wife's education & 0,769 & $0,012^{*}$ & 2,158 & $1,182-3,941$ \\
\hline Income & 0,738 & $0,022^{*}$ & 2,092 & $1,111-3,936$ \\
\hline Communication & 0,953 & $0,010^{* *}$ & 2,594 & $1,262-5,333$ \\
\hline Culture & 4,385 & $0,000^{* *}$ & 80,22 & $29,7-216,5$ \\
\hline
\end{tabular}

Information: $*=\mathrm{p} \leq 0,05 ; * *=\mathrm{p} \leq 0,01 ; ; * * *=\mathrm{p} \leq 0,001$

\section{DISCUSSION}

\subsection{Level of male participation in childbirth}

This study found that more than half of the respondents had high participation in childbirth of their wives in Muaro Jambi District (54.1\%). This phenomenon could be seen from the high proportion of 4 out of 6 supporting indicators, including planning the time and place of childbirth $(73.8 \%)$, preparing funds for delivery costs $(78.2 \%)$, bring the wife at giving birth (88.5\%), and accompanying during childbirth (61.9\%). Meanwhile, 2 indicators that were low were planning potentially blood donors for emergency delivery (18.6\%) and preparing vehicles needed when the wife gave birth $(47.8 \%)$. These results were in line with previous studies in El Salvador and Indonesia [12], but differ from other studies conducted in Tanzania and Northern Nigeria [8][9]. The childbirth process requires physical and mental readiness because $86 \%$ of pregnant women experience stress in the 3rd trimester of pregnancy due to one of the reasons for fear of the childbirth process 12 . The role of male is very important and affects the success and smoothness of the wife's delivery process [13][14].

\subsection{Determinant of male participation in childbirth}

This study found 5 variables that simultaneously have a significant relationship with male participation in childbirth including age $(\mathrm{OR}=2.148)$, wife's education $(\mathrm{OR}=2.158)$, income $(\mathrm{OR}=2.092)$, communication $(\mathrm{OR}=2.594)$, and culture $(\mathrm{OR}=80.22)$. This finding further adds to the complexity of the problem and the concept of male participation in maternal health, especially during childbirth.

Men aged $>30$ years show maturity level and have experience with the wife's pregnancy process, so they tend to participate more in this study. Previous studies in Indonesia also found a greater tendency for husbands to accompany the delivery of wives aged $21-35$ years, meaning that the age of the husbands is higher [12]. This finding is different from the studies of Gibore, et al (2019) and Iliyasu, et al (2009) which prove that age is not related to the level of male participation in childbirth
[8][9]. A study in Ungogo, Northern Nigeria found that men aged $<30$ years were more likely to participate in childbirth than those aged $\geqslant 30$ years [8].

This study showed that the wife's education is related to her husband's participation in the delivery process. The variations in preparedness for childbirth were also caused by differences in women's literacy levels [8]. Higher education will encourage women to seek information, preferences and literature about preparation for birth and to be more communicative with their husbands. In addition, high knowledge will make the wife have autonomy in her health, choose the right method and facilities for childbirth, and quickly make rational decisions for the safety of herself and her baby [15].

One of the inhibiting factors for male participation in childbirth is insufficient funds, so they prefer to stay at home to reduce expenses. Men with low-income types of work generally find it difficult to find time to participate in the delivery [16] process of their wives. In terms of gender roles, unique results were found in a study in Nigeria where the husband's role in the wife's health care was considered sufficient by providing money for childbirth costs and ensuring the wife could eat adequately, without having to accompany the wife during childbirth10. More than half of the respondents $(69 \%)$ in this study have low income $(<$ Rp. $2,500,000$ per month), so the concern that high delivery costs tends to affect male participation. More than $50 \%$ of respondents admitted that they spent up to 1 million rupiah for delivery. Interestingly, of the 202 respondents (77.4\%) who used health insurance, only 77 respondents (20.2\%) claimed to receive free delivery services. This fact should be a concern for the local government (Health Office) to provide assurance of health insurance for the community.

Good communication between partners tends to increase male participation in childbirth, otherwise the lack of communication causes men to be limited in understanding women's reproductive needs, so that they have no intention of seeking health care for their wives, including childbirth. Decision making in seeking and obtaining childbirth services is a process that requires communication between the husband and wife. Good and effective communication results in positive support from males through increased participation in the birth 
process which has an impact on the health of mothers and children [9].

Culture influences male participation in women's reproductive health which can act as a barrier to male participation in childbirth [10][16]. This study proves that the high male participation in childbirth is related to the strength of cultural support. The dominance of men in the main decision-making in the family, including the issue of childbirth, is reinforced by patriarchal culture, religion and economic power as the sole breadwinner. This is a social stigma and traditional gender roles that can hinder male participation in maternal and child health [11]. Traditional culture considers women reproductive workers and seems to delegate the realm of childcare and maternal health to women only, while men were considered productive workers who earned money. This study reveals that the cultural factor was the most important determinant associated with male participation in childbirth. This shows that although only a small number of men has cultural barriers, this is still being resisted so that change occurs because if not, men's involvement will always focus on financial support and decision making [12].

\section{CONCLUSION}

Most of the males have high participation in childbirth in Muaro Jambi District, especially planning the time and place of childbirth, preparing funds for childbirth costs, delivering the wife to give birth, and accompanying the wife during childbirth. While the participation is preparing vehicles, and planning potential blood donors for emergency delivery, it still needs to be improved. Simultaneously, the factors related to male participation in childbirth were age, wife's education, income, communication and culture. Cultural factor was the most important determinants of male participation in childbirth. It is necessary to disseminate information and advocacy personally and structurally in society to reduce barriers to male participation which can reduce gender inequality in decision making and actions that support the improvement of maternal health, especially childbirth.

\section{REFERENCES}

[1] Bappenas. (2018). Retrieved from https://www.sdg2030indonesia.org

[2] Kemenkes RI. 2013. Keputusan Direktur Jenderal Bina Upaya Kesehatan Nomor HK.02.03/II/1911/2013 Tentang Pedoman Penyelenggaraan Puskesmas Mampu Pelayanan Obstetri Neonatal Emergensi Dasar (PONED). Jakarta. Available at: http://cdn.stikesmucis.ac.id/PEDOMAN $\% 20 \% 20 \mathrm{P}$ ENYELENGGARAAN\%20\%20PUSKESMAS \%2 OMAMPU\%20PONED.pdf
[3] Z. Iliyasu, I. S. Abubakar, H. S. Galadanci, \& M. H. Aliyu. (2010). Birth preparedness, complication readiness and fathers' participation in maternity care in a northern Nigerian community. African Journal of Reproductive Health, 14(1), 21-32. https://doi.org/10.2307/25766336

[4] N. S. Gibore, M. J. Ezekiel, A. Meremo, M. J. Munyogwa, \& S. M. Kibusi. (2019). Determinants of men's involvement in maternity care in dodoma region, central Tanzania. Journal of Pregnancy, 2019. https://doi.org/10.1155/2019/7637124

[5] C. Mbadugha, C. Anetekhai, A. Obiekwu, I. Okonkwo, \& J. Ingwu, (2019). Adult male involvement in maternity care in Enugu State, Nigeria: A cross-sectional study. European Journal of Midwifery, 3(September), 1-7. https://doi.org/10.18332/ejm/112258

[6] UNICEF. (2011). Gender Influences on Child Survival, Health and Nutrition: A Narrative Review. Medicine, UNICEF and Liverpool School of Tropical. New York: UNICEF. Retrieved from https://www.unicef.org/Gender Influences on Chi ld_Survival_a_Narrative_review.pdf

[7] R. Rumaseuw, S. M. Berliana, N. Nursalam, F. Efendi, R. Pradanie, P. D. Rachmawati, \& G. E. Aurizki. (2018). Factors Affecting Husband Participation in Antenatal Care Attendance and Delivery. IOP Conference Series: Earth and Environmental Science, 116(1). https://doi.org/10.1088/1755-1315/116/1/012012

[8] B. H. Mohammed, J. M. Johnston, D. Vackova, S. M. Hassen, \& H. Yi. (2019). The role of male partner in utilization of maternal health care services in Ethiopia: A community-based couple study. BMC Pregnancy and Childbirth, 19(1), 1-9. https://doi.org/10.1186/s12884-019-2176-z

[9] F. O. Bello, P. Musoke, Z. Kwena, G. O. Owino, E. A. Bukusi, L. Darbes, \& J. M. Turan. (2019). The role of women's empowerment and male engagement in pregnancy healthcare seeking behaviors in western Kenya. Women \& Health, $59(8)$,

892-906. https://doi.org/10.1080/03630242.2019.1567644

$[10]$ N. S. Gibore, T. A. L. Bali, \& S. M. Kibusi. (2019). Factors influencing men's involvement in antenatal care services: a cross-sectional study in a low resource setting, Central Tanzania. Reproductive Health, 16(1), 52. https://doi.org/10.1186/s12978-019-0721-x

[11]M. M. Kamal, M. S. Islam, M. S. Alam, \& A. B. M. E. Hasssn, (2013). Determinants of Male Involvement in Family Planning and Reproductive 
Health in Bangladesh. American Journal of Human Ecology, 2(2), 83-93. https://doi.org/10.11634/216796221302332

[12] M. W. Carter, \& I. Speizer. (2005). Salvadoran fathers' attendance at prenatal care, delivery, and postpartum care. Revista Panamericana de Salud Publica/Pan American Journal of Public Health, 18(3), 149-156. https://doi.org/10.1590/S102049892005000800001

[13] S. Sapkota, T. Kobayashi, \& M. Takase. (2013). Impact on perceived postnatal support, maternal anxiety and symptoms of depression in new mothers in Nepal when their husbands provide continuous support during labour. Midwifery, 29(11), 1264-1271. https://doi.org/10.1016/j.midw.2012.11.010

[14] M. W. O’Hara, \& K. L. Wisner, (2014). Perinatal mental illness: Definition, description and aetiology. Best Practice and Research: Clinical Obstetrics and Gynaecology, 28(1), 3-12. https://doi.org/10.1016/j.bpobgyn.2013.09.002

[15] B. C. Mullany, M. J. Hindin, \& S. Becker. (2005). Can women's autonomy impede male involvement in pregnancy health in Katmandu, Nepal? Social Science and Medicine, 61(9), 1993-2006. https://doi.org/10.1016/j.socscimed.2005.04.006

[16] F. K. Ongolly, \& S. A. Bukachi. (2019). Barriers to men's involvement in antenatal and postnatal care in Butula, western Kenya. African Journal of Primary Health Care and Family Medicine, 11(1), 1-7. https://doi.org/10.4102/phcfm.v11i1.1911 